\author{
Alizada C. Sh., Valiyeva A.Q., \\ Aliyev B.A.
}

DOI: $10.25108 / 2304-1730-1749 . i o l r .2018 .54 .6-31$

\title{
The problems that extremism has created in the modern epoch and some aspects of struggling with it
}

\begin{abstract}
Nowadays multiple countries of the world suffer from religious extremism and terror seriously. By the cause of terror events social stability is disturbed in several regions of the world, civil confrontation arises and millions of people live refugee and wanderer life, historical architectural monuments and schools are being destroyed. The exploitation of religion that causes the welfare and happiness to the society by the terrorist and extremist groups in a way that threatens the peace and trust of the population creates a great threat for the state security. From this perspective, the directing of the significant role and effect of religion that plays in human's spirit, morality and social consciousness to the right course is an important issue.

In the modern epoch ensuring of freedom of religious beliefs which is being one of the fundamental human rights plays a special role in politics and intercommunications of some countries. Today, it's the significant duty and responsibility of the government to approach to the issues related to religion not only from the aspect of human rights and national moral values, but also from the aspect of security. Though religion is separate from the state, the state is directly

\footnotetext{
"Alizada Cavid Shirzad oglu - Researcher of the Department of "The legal provision of state security" of the Institute on Law and Human Rights of the Azerbaijan National Academy of Sciences (Azerbaijan). E-mail: cavid6455@mail.ru

Valiyeva Aynur Qahraman qizi - Researcher of the Department of "The legal provision of state security" of the Institute on Law and Human Rights of the Azerbaijan National Academy of Sciences (Azerbaijan). E-mail: veliyevaa3@gmail.com

Aliyev Bakhtiyar Abdurahman oglu - PhD in Law, Associate Professor, Head of the Department of "The legal provision of state security" Institute on Law and Human Rights of Azerbaijan National Academy of Science, (Azerbaijan). E-mail: antiterror-baku@mail.ru
} 
responsible for the religious situation in the state and ensuring of security of the citizens.

Also today our country is still successfully keeping up the acts in the direction of preventing religious extremism, protecting our citizen from external effects, stabilizing the religious situation in our country, ensuring of the security of the population. The legislative basis is constantly improving to harmonize normativelegal acts with international norms, precise definition of the rights and obligations of the state and religious institutions, as well as to limit the activities of the sectarian and anti-hate propaganda that contradict humanism principles.

Today, law enforcement agencies of the Republic of Azerbaijan carry out successive and systematic events to prevent extremism and radical tendencies in the country. The failure of the radical sects to spread in our country, and the actions carried out in relation to young people fighting in the armed forces operating abroad, confirm this idea.

Keywords: religious extremism; religious radicalism; struggle against religious extremism; interfaith dialogue; social problems.

Son illər dünyada regional və qlobal müstəvidə baş verən hadisələr yüksək əxlaqi dəyərlərin təbliği, insanların birlik və bərabərliyinin təmin edilməsi, sülhün və əmin-amanlığın qorunması missiyasını daşıyan dinlərdən müasir dövrdə siyasi məqsədlərin və məkrli niyyətlərin həyata keçirilməsində geniş istifadə olunduğunu göstərir. Hazırda dünyada, xüsusilə müsəlman ölkələrində sabitliyin pozulmasında din amili xüsusi rol oynayır və beynəlxalq güclər bu vəziyyətdən məharətlə istifadə edir. Bu müəyyən şəxslər və qurumlar tərəfindən yaradılan çoxsaylı hərəkat və cərəyanların timsalında özünü açıq büruzə verir [1].

Müasir dövrdə dünyanın bir çox dövlətləri dini ekstremizm və terrordan ciddi əziyyət çəkir.Radikalizm və ekstremizmin yaranmasının müxtəlif obyektiv və subyektiv səbəbləri var və bu özünü bir çox sahələrdə göstərir. Dövlət siyasətində 
ayr1-seçkiliyə rəvac verilməsi, dinlərarası münasibətlərin gərginləşdirilməsi, bir sıra hallarda dini dəyərlərin təhqir olunması, dini zəmində ədavət və düşmənçiliyin qızışdırılması bu səbəblərdəndir [2].

Azərbaycan Respublikasında dini ekstremizm təhlükəsi keçən əsrin 90-c1 illərindən meydana çıxmağa başlamış, müstəqilliyin ilk illərində respublikada siyasi stabilliyin pozulması, Ermənistanla silahlı münaqişə və iqtisadi durumun çətinləşməsi ölkədə xeyli problem yaratmışdır. Yetmiş ildən artıq bir müddətdə sovet rejiminin ateizm təbliğatına məruz qalan, din xadimlərinin fəaliyyətinə və dini maarifləndirmənin aparılmasına qadağa qoyulan ölkəmizdə dini fəaliyyət sahəsində bir sıra problemlər özünü açıq göstərir, əhalinin böyük bir hissəsinin din barəsində məlumatsızlığı, dinlərin fəlsəfəsinə, Azərbaycanda yayılması tarixinə və xüsusiyyətlərinə dair biliklərinin yetərsizliyi radikal dini təriqətlərin respublikada yayılmasına əlverişli şərait yaradırdı. Lakin, Heydər Oliyevin dövlət-din münasibətlərinə strateji baxışı sayəsində dini etiqad azadlığı ilə bağlı qanunvericiliyin təkmilləşdirilməsi, institusional islahatların aparılması, dini abidələrin bərpası, yenidən qurulması istiqamətində konkret addımlar atılmışdır.

$\mathrm{Bu}$ sahədə görülən işlərdən biri xaricdə dini təhsil almış və zərərli dini təsirlərə məruz qalmış gənclərin məscidlərə din xadimi təyin edilməsinin qarşısının alınmas1 məqsədilə 2015-ci ildə "Dini etiqad azadlığı haqqında" Azərbaycan Respublikasının Qanununa bir sıra əlavə və dəyişikliklər edilməsidir. Sözügedən Qanunun 21-ci maddəsinin 3-cü bəndinə əsasən "İslam dininə aid ayin və mərasimlərin aparılması yalnız Azərbaycan Respublikasının vətəndaşları tərəfindən həyata keçirilə bilər. Xaricdə dini təhsil almış Azərbaycan Respublikasının vətəndaşlarına islam dininə aid ayin və mərasimlərin aparılması qadağandır"[3, s.74]. Burada əsas məqsəd xaricdə təhsil alarkən yad ideoloji təsirlərə məruz qalmış şəxslərin ölkədə din xadimi kimi fəaliyyət göstərmələrinin, dini ibadət yerlərində və ictimaiyyət arasında zərərli dini təbliğat aparmalarının qarşısının alınmasıdır. 
Ekstremizmə qarşı mübarizənin gücləndirilməsi və radikallıq meyllərinin qarşısının alınması ilə bağlı müddəalar Azərbaycan Respublikasının Qanunlarında da öz əksini tapmışdır. Azərbaycan Respublikasının Cinayət Məcəlləsinin 12.1, 279.1-ci (Azərbaycan Respublikasının qanunvericiliyi ilə nəzərdə tutulmayan silahlı birləşmələr və ya qruplar yaratma, eləcə də onların yaradılmasında və fəaliyyətində iştirak etmə, onları silahla, döyüş sursatı ilə, partlayıcı maddələrlə, hərbi texnika ilə, yaxud əsgəri ləvazimatla təchiz etmə), 28, 283-1.3-cü və 283-1.3cü (Azərbaycan Respublikası vətəndaşlarını və ya Azərbaycan Respublikasında daimi yaşayan vətəndaşlı̆̆ olmayan şəxsləri dini məzhəbləri yaymaq, dini ayinlərin icrası adı altında, yaxud dini düşmənçilik zəminində Azərbaycan Respublikasının hüdudlarından kənarda aparılan silahlı münaqişələrə cəlb etmə, yaxud bu məqsədlə döyüş təlimləri keçmə, yaxud həmin məqsədlə fəaliyyət göstərən sabit qrup yaratma və ya belə qrupa rəhbərlik etmə, eləcə də həmin qruplarda, təlimlərdə və ya silahlı münaqişələrdə iştirak etmə, yaxud bu ağır cinayətlərə hazırlıq) maddələri ekstremizmə qarşı mübarizədə xüsusi əhəmiyyətə malikdir [3,s.188].

2015-ci ilin dekabr ayında Azərbaycanda "Dini ekstremizmə qarşı mübarizə haqqında" Qanun qəbul edilmişdir. Bu Qanunun qəbul edilməsi milli, sosial və ya dini nifrətin salınmasının, milli ləyaqətin alçaldılmasının, milli, irqi, sosial və ya dini mənsubiyyətindən asılı olaraq vətəndaşların hüquqlarının məhdudlaşdırılmasının və ya üstünlüklərinin müəyyən edilməsinə yönələn hərəkətlərin törədilməsinin qarşısının alınmasına ciddi töhfələr vermişdir.

Dini radikalizm: hər hansı dinin, məzhəbin, cərəyanın üstünlüyünü, xüsusi imtiyaza malik olduğunu təbliğ edərək digər etiqadın ardıcıllarına qarşı dözümsüz münasibət göstərən ifratçı sosial-dini fenomendir. Radikalizmin bu forması yeni ictimai hadisə deyildir. Tarix boyu din və məzhəb zəmində qanlı münaqişələr baş vermiş, günahsız insanların qanı axıdılmışdır. Varfolomey gecəsi, səlib yürüşləri və digər tarixi hadisələr bunun bariz nümunəsidir. Son əsrlər bəşəriyyətin elmi- 
texnoloji, sosial-siyasi cəhətdən sürətlə irəliləməsinə, yer kürəsinin kiçik bir kəndə dönməsinə baxmayaraq, dini radikalizm aktuallığını itirməmiş, əksinə, yeni qiyafəyə bürünərək qlobal təhlükə halını almışdır. Ominliklə demək olar ki, günümüzdə radikalizmin ən təhlükəli forması dini ekstremizmdir.

Bəzi araşdırmaçılara görə, müasir dünyada ifrat dini təmayüllər özünü üç şəkildə - sırf dini, dini-etnik və dini cəhətdən əsaslandırılmış siyasi radikalizm formasında göstərirlər [4, s. 165].

Sırf dini radikalizm dedikdə "xarizmatik" ruhani liderlər ətrafinda birləşən azsaylı, lokal qruplar, daha doğrusu, dini sektalar nəzərdə tutulur. Belə sektaların rəhbərləri irimiqyaslı sosial təlatümlərə, siyasi etirazlara səsləməsələr də, onların dini təlimləri radikal səciyyə daşıyır. Belə ki, bu ruhani liderlər qapalı qruplarına, azsaylı tərəfdarlarına alternativ sosial-dini layihələri (məs., ailədən üz döndərmək, cəmiyyətlə əlaqəni kəsmək, təhsildən, tibbi yardımdan, elmi-texnoloji nailiyyətlərdən imtina etmək, sivil dünyadan ayrılmaq və s.) həyata keçirməyi tapşırırlar. Adətən bu sektalarda ənənəvi ailə institutu inkar olunur, yeni ailə modelinin formalaşdırılması istiqamətində səylər göstərilir. Bununla yanaşı, sözügedən sektalarda ibtidai təsərrüfat formasına, patriarxal ailə quruluşuna üstünlük verilir, üzvlər kommuna (birgə) şəklində yaşayır, davamlı dünyanın sonunu gözləyirlər [4, s. 165].

Bu sektalardan biri Mun Son Myonun yaratdığı "Vəhdət Kilsəsi”dir. Həmin kilsənin ardıcılları (munçular) dini rəhbərlərini - Mun Son Myonu və onun həyat yoldaşı Hakca Han Munu bəşəriyyətin və özlərinin "həqiqi valideynləri” sayır, yaxınlarından, sosial həyatdan uzaqlaşır, bir sözlə, qapalı həyat tərzi sürürlər.

Sırf dini radikalizm növü ardıcıl sayı baxımından geniş yayılmasa da, hər hansı toplum üçün təhlükə törədir. Çünki destruktiv səciyyə daşıyaraq, bilavasitə ictimai münasibətlərə və sosial dəyərlərə qarşı çıxır, dini-sosial fanatizmin əsasını qoyur, qeyri-qanuni fəaliyyətə vadar edir [4, s.166]. 
Dini radikalizmin digər növü olan dini-etnik radikalizmə özündə müxtəlif mühafizəkar, ənənəçi ideyaları birləşdirən qruplar aiddir. Belə qruplar etnik dinin dirçəldilməsi, etnik cəhətdən təmiz cəmiyyətin və dövlətin qurulması uğrunda mübarizə aparırlar. Dini-etnik radikal qruplar siyasi-iqtisadi qloballaşmanı və dünya dinlərini tənqid atəşinə tutan utopik layihələr hazırlanır, etnososialist, biosiyasi, biohüquqi, bioiqtisadi fikirlər müdafiə olunur, elmi-texnoloji tərəqqiyə qarşı çıxı1ır. Məsələn, günümüzdə Rusiya, Ukrayna və Belorusiyanın bəzi ziyalıları panslavyanizm ideologiyası ətrafında birləşiblər. Onlar qloballaşmanı, Avropa Birliyini tənqid hədəfinə çevirərək slavyan xalqlarını superetnos sayır, bu xalqları ortaq siyasi-mədəni keçmiş səbəbi ilə vəhdətə səsləyirlər. Həmçinin dini-etnik radikalizmə misal kimi, Polşadakı "Rodzima Wiara", Latviyadakı "Dievturiba" adlı dini-siyasi hərəkatları göstərmək mümkündür. Dünya dinlərinə (Xristianlıq, İslam və s.) mənfi münasibət bəsləyən dini-etnik radikalizm ekstremizm üçün ideoloji mənbəyə çevrilərək cəmiyyətdə təhlükəli qüvvə ola bilər [4, s. 166].

Dini cəhətdən əsaslandırılmış dini radikalizm növünə isə zor gücü ilə hakimiyyəti dəyişdirməyə və ya ələ keçirməyə, hər hansı dövlətin suveren hüquqlarını pozmağa, qanunsuz silahlı birləşmələr yaratmağa, dini-etnik nifrət zəminində təxribata əl atmağa səsləyən ideologiya və fəaliyyətlər aiddir. Bu, dini radikalizmin ən təhlükəli formasıdır. Çünki tərifindən də göründüyü kimi, ekstremist fəaliyyət və terror aktlarının həyata keçirilməsi yolu ilə siyasi hədəfə çatmağa çalışılır. "IŞSiD”, “əl-Qaidə”, "Boko Haram” kimi terror təşkilatları sözügedən radikalizm formasının bariz nümunələridir.

Qloballaşma dövründə dini ekstremizm bir çox ölkənin problemi halına gəlmişdir. Artıq, dini ekstremizmlə mübarizə milli sərhədləri aşaraq, beynəlxalq əməkdaşlıq tələb edir. Günümüzdə bu problemlə mübarizə, siyasi olduğu qədər hüquqi aspektləridə özündə əks etdirir. Getdikcə daha çox milli və beynəlxalq sülhü təhdid edən bir problem halına gələn dini ekstremizm ilə mübarizədə milli və beynəlxalq hüquqi aktlar hazırlanmadan əvvəl problemin xüsusiyyətlərini 
müəyyənləşdirmək, mövcud iqtisadi, siyasi, sosial, tarixi, ictimai və mədəni şəraiti nəzərdən keçirmək lazımdır. Bütün bu amillər problemin həllinin müsbət nəticələnməsinə gətirib çıxarır. Dini ekstremizmlə mübarizədə ümumi problemlər, beynəlxalq hüququn xüsusiyyətlərindən qaynaqlanan və dünyanın fərqli bölgələrində fərqli siyasi və ictimai xüsusiyyətlər üzərinə qurulan dövlətlərin əməkdaşlıq çətinliyindən irəli gəlir. Bu da problemə düzgün yanaşılmasına maneə törədir va həllini çətinləşdirir.

Dini ekstremizmlə mübarizənin ümumi problemlərinə aşağıdakı faktorların təsiri vardır:

1. Ekstremizm ilə mübarizə aparmaq üçün beynəlxalq müqavilənin olmamas1.

2. Dini ekstremizm anlayışının beynəlxalq hüquqi tərifinin olmaması.

3. Beynəlxalq elmi əməkdaşlıq sahələrində, dini ekstremizmlə mübarizə ilə bağlı mövzularla əlaqədar əhatəedici araşdırma və iş sisteminin qurulmamış olmasi.

$\mathrm{Bu}$ gün ekstremizmlə mübarizədə ən səmərəli metodlardan biri maarifləndirmə işinin gücləndirilməsi, insanların, xüsusilə də gənc nəslin dini biliklərinin artırılmasıdır. Ümumi təhlillər gənclərin bu təsirlərə daha çox dini biliklərinin zəif olması və savadsızlıq səbəbindən məruz qaldıqlarını göstərir. Bunun üçün dini təhsil müəssisələrində təhsilin səviyyəsinin yüksəldilməsi, madditexniki bazanın gücləndirilməsi, dini dərslərlə yanaşı dünyəvi fənlərin tədrisi, əhatəli və dərin məzmunlu dərs vəsaitlərinin hazırlanmas1, tədrisin hər hans1 məzhəbçilik deyil, ümumi prinsiplər əsasında təşkil olunması, xurafatçılığa yol verilməməsi və tələbələrə vətənpərvərlik ruhunun aşılanması xüsusi əhəmiyyət kəsb edir.

Dövlətimiz dini ekstremizmin qarşısının alınması, vətəndaşlarımızın xarici təsirlərdən qorunması, ölkədəki dini durumun sabit saxlanılması, əhalinin təhlükəsizliyinin təmin edilməsi istiqamətində tədbirləri bu gün də uğurla davam etdirir. Normativ-hüquqi aktların beynəlxalq normalara uyğunlaşdırılması, 
dövlətin, həm də dini qurumların hüquq və öhdəliklərinin dəqiq müəyyən olunması, eləcə də insanpərvərlik prinsipləri ilə ziddiyət təşkil edən zərərli fikirləri təbliğ edən təriqət və cərəyanların fəaliyyətinin məhdudlaşdırılması məqsədilə qanunvericilik bazası mütəmadi olaraq təkmilləşdirilir.

Azərbaycan Prezidenti İlham Oliyevin rəhbərliyi ilə ölkəmizdə həyata keçirilən fəal hüquq-mühafizə və təhlükəsizlik siyasətinin əsas istiqamətlərinə dair gənclərin məlumatlandırılması, şəxsiyyətin, cəmiyyətin və dövlətin təhlükəsizliyi əleyhinə yönəlmiş təhdidlərin, xüsusilə terrorçuluğun, ekstremizmin və radikalizmin mahiyyəti, yaranma şəraiti, gerçəkləşdirilmə üsulları və onlardan qorunma yolları barədə maarifləndirmənin təşkili mühüm məsələdir. Həmçinin dövlət təhlükəsizliyinə mümkün təhdidlərin qarşısının alınmasında ən səmərəli vasitə olan vətənpərvərlik, dövlətçilik amallarının, milli-mənəvi irsin, adətənənələrin aşılanması, cəmiyyətin, əsasəndə gənc nəslin dini dözümlülük və tolerantlıq mədəniyyətinin inkişaf etdirilməsi ruhunda tərbiyə olunması, eləcə də ölkə gənclərinin aparıcı nümayəndələri, müxtəlif dövlət və ictimai təşkilatların təmsilçiləri ilə terrorçuluq, ekstremizm və radikalizmə qarş1 effektiv mübarizə mexanizmlərinin yaradılması istiqamətində birgə səyləri müzakirə etmək, ayr1-ayr1 qurumların səylərinin birləşdirilməsi, fəaliyyətinin əlaqələndirilməsi vacib məsələdir.

Dünyada sülhün və beynəlxalq təhlükəsizliyin möhkəmləndirilməsi naminə dini birliklər arasında əməkdaşlığın vacibliyini dərk edən gənc, fəal, təhsilli, geniş düşüncəli insanların böyük qrupları dinə müraciət etməkdədir. Dinlərarası dialoqun mütləq şərtlərindən biri onun iştirakçılarının tolerantlığ 1 və bir-birinin dini etiqadına hörmətlə yanaşmasıdır. Dinlərarası əməkdaşlığın iştirakçısına qarşı dözümsüzlük, onun ardıcılı olduğu dini etiqada hörmətsizlik labüd surətdə dinlərarası münasibətlərin kəskinləşməsinə səbəb olur [5, s. 69]. Din xadimləri və sıravi dindarlar dərk edir ki, dinlər arasında daimi dialoq böyük fayda verə bilər. 
Birincisi, belə dialoq dinlərarası ziddiyyətlərin aradan qaldırılmasına (ya da heç olmasa yumşaldılmasına), dinlər və konfessiyalar arasında ideoloji yarışın sivil çərçivədə getməsinə təkan verə bilər, bu isə etno-milli münasibətlərə və ictimaisiyasi sabitliyə müsbət təsir göstərərdi.

İkincisi, dinlərarası dialoq siyasətçilər və din xadimləri arasında özlərinin siyasi iddialarını gerçəkləşdirmək üçün dinlərin səfərbəredici potensialından yararlanmağa meylli radikallar qarşısında maneə yarada bilər.

Üçüncüsü, dinlərarası dialoq bəşəriyyətə fəlakətlər gətirən qlobal təhdidlərə qarş1 mübarizədə müxtəlif dini etiqadlara və millətlərə mənsub insanların səylərinin birləşdirilməsinə kömək göstərərdi.

Dördüncüsü, dinlərarası dialoq cəmiyyətə belə bir faktı dərk etməyə imkan verərdi ki, dinisiyasi ekstremizmin və beynəlxalq terrorizmin əsasında duran real səbəbləri bu və ya digər dini təlimdə axtarmaq perspektivsizdir. $\mathrm{Bu}$ isə belə təzahürlərin həqiqi səbəblərinin və son nəticədə onlara qarş1 səmərəli mübarizə üsullarının axtarılmasını asanlaşdırardı.

Nəhayət, beşincisi, dinlərarası dialoq yalnız dini-siyasi ekstremizm və beynəlxalq terrorizm təzahürlərinin hamı tərəfindən qinanması üçün deyil, həm də gələcəkdə belə cinayət əməllərinin qarşısının alınmasına yönəlmiş zəruri tərbiyə işinin qurulması üçün imkan yaradardı.

Dinlərarası dialoqun millətlərarası münasibətlərə başlıca təsiri, onların humanistləşdirilməsinə töhfəsi onun insanlara tərbiyəvi təsiri vasitəsilə mümkündür. Belə dialoq müxtəlif millətlərə və dini etiqadlara mənsub insanların şüuruna tolerantlıq, zorakılığın yolverilməzliyi və sülh mədəniyyəti ruhunda təsir göstərir.O, cəmiyyət üzvlərini başqa millətlərə və dini etiqadlara mənsub insanların şəxsində etimada layiq bərabərhüquqlu tərəfdaşları görməyə alışdırır. Konfessiyalararası dialoq əhalidə dini plüralizmə və mədəni müxtəlifliyə hörmətin formalaşmasına təkan verir. 
Qeyd olunanlardan birmənalı surətdə bu nəticəyə gəlmək olar ki, dinlərarası dialoq sivilizasiyalar arasında dialoqun mühüm komponentidir.Sivilizasiyalar arasında münasibətlərdə ahəngdarlığın yaradılması, xalqlar arasında sülhün qorunub saxlanması və möhkəmləndirilməsi üçün dinlərarası dialoq böyük əhəmiyyət daşıyır.Bu, yalnız dinlərin arxasında çoxmilyonluq xalq kütlələrinin durması ilə bağlı olmayıb, həm də dinlər arasında dərin ideoloji ziddiyyətlərin mövcudluğu ilə şərtlənir, həmin ziddiyyətlərin kəskinləşməsi isə ciddi münaqişələrə səbəb ola bilər.

Ümumiyyətlə radikal qrupların meydana gəlməsinin səbəbləri müxtəlifdir. $\mathrm{Bu}$ ayr1-ayrı ölkələrdə ayr1-ayrı səbəblər üzündən ola bilər. Dini bilməməzlikdən olur. Bəzən elə yaşda olur ki, macəra axtarışında olur. Elə adamlar var ki, gənc yaşındadır, - "uğur əsgərləri” deyirlər, - elə bilir ki, müharibəyə getmək, hansısa vuruşda iştirak etmək ona uğur gətirə bilər. $\mathrm{Bu}$ cür düşünənlər də var. Burada əlbəttə radikal dini qrupların təbliğat-təşviqatı da rol oynayır. Biz əgər ümumiləşmiş şəkildə desək Azərbaycanda bu cür qruplara qoşulanların sırasında macəra axtaranlar və "uğur əsgəri" kimi çıxış etmək istəyənləri daha çox görə bilərik. Yəni sosial baxım, iqtisadi baxım axırıncı yerdə durur. Çünki gedib qanunsuz silahlı birləşmələrə qatıldığ 1 ölkələrdən Azərbaycan sosial həyat tərzinə görə, inkişafina görə qat-qat üstün vəziyyətdədir. Burada dini təbliğat vasitə ola bilər. Bir də dini zəif bilməyin də burada bəzən təsiri ola bilər.

Mürəkkəblik dini ideologiyanın yanlış izahatla siyasi ideologiyaya çevrilə bilməsindən, dini radikallığın isə sonradan siyasi radikallığa dönüşməsi potensialından da qaynaqlanır. Bütün bunlar dövlətin qarşısına bir-biri ilə əlaqəli kompleks problemlər kimi çıxanda, onların yalnız inzibati metodlarla həlli bir çox halda gözlənilən nəticəni nəinki vermir, hətta əks təsir göstərərək problemi daha da dərinləşdirir. Ona görə də dini radikalizmlə mübarizədə inzibati tədbirlər ən sonuncu çarə sayılmalı, problemin ilkin çözümü üçün ideoloji müstəvidə aktiv iş aparılmalıdır. Məhz bu baxımdan ictimai qınağın effektiv təsirlərindən 
yararlanmaq vacibdir ki, bu məsələdə dini ictimaiyyət, xüsusilə də dini icmalar daha aktiv olmalıdırlar.

Amma hər şeydən əvvəl problemi dərindən, hərtərəfli öyrənmək lazımdır ki, daha sonra onunla effektiv mübarizə aparmaq mümkün olsun. Bu zaman ilk olaraq qarşımıza belə bir sual çıxır: hansı dini qruplar radikal hesab olunur? Bu suala elmi ədəbiyyatda birmənalı cavab yoxdur. Amma 3 istiqamətdə fəaliyyət göstərənləri radikal dini qruplar hesab etmək olar:

1. Öz dini görüşünü başqalarına zorla qəbul etdirməyə çalışanlar.

2. Başqalarının dini dünyagörüşlərinə hörmətlə yanaşmayaraq, birgəyaşayış ənənəsinə qarşı çıxanlar.

3. Siyasət də daxil olmaqla, cəmiyyətin bütün sahələrini öz dini görüşləri istiqamətində tənzimləməyə çalışanlar.

"Dini ekstremizmə qarşı mübarizə haqqında" Azərbaycan Respublikasının Qanununda isə dini radikalizm - hər hansı dini etiqad çərçivəsində ifrat dini baxışlara bağlılı̆̆1 ifadə edən, həmin dini baxışların müstəsnalığının təsbit edilməsində barışmaz mövqe nümayiş etdirən və yayılmasında aqressiv üsul və vasitələrdən istifadə edilməsi ilə səciyyələnən davranış kimi göstərilmişdir.

$\mathrm{Bu}$ problemlərin qarşısını fətva, seminar və konfranslarla almaq mümkün deyil. Zərərli təsirlərə məruz qalmış gənclərin çoxu bu fətvaları qəbul etmir və həmin tədbirlərdə iştirak etmirlər. Eyni zamanda, qarşıllıq ittihamlar vəziyyəti daha da gərginləşdirir. Burada inzibati tədbirlərdən daha çox geniş və sistemli maarifləndirmə işlərinin həyata keçirilməsinə böyük ehtiyac var. Ölkə vətəndaşlarının bütün təbəqələrini əhatə edən təbliğat planı hazırlanmalı, zəngin biliklərə malik din xadimləri, elm adamları və ziyalılar bu proseslərə cəlb olunmalı, dindarları narahat edən məsələlər, həmçinin sosial problemlər diqqətlə öyrənilməli və onların həlli istiqamətində zəruri addımlar atılmalıdır.

Son dövrlər bir sıra müsəlman dövlətlərində radikallıq meyillərinin artması və qarşıdurmaların yaranması bilavasitə bölgədə və dünyada baş verən proseslərlə sıx 
bağlıdır. Müsəlman ölkələrində cərəyan edən siyasi hadisələr, daxili qarşıdurmalar, sosial problemlərin uzun müddət həll olunmaması və münaqişələrin həllinə ikili standartlarla yanaşma bu meyillərin artmasına münbit şərait yaradır. Eyni zamanda, bir sıra hallarda insan hüquq və azadlıqlarının pozulması, insanların fikirlərini azad ifadə edə bilməmələri, sosial durumlarının yaxşı olmaması, özlərini cəmiyyətdən təcrid olunmuş hiss etmələri radikallığın artmasına güclü təkan verir. Hadisələrin bu şəkildə gedişatı və inkişafı həmin proseslərin getdikcə daha kəskin xarakter alacağını, daha geniş coğrafi əraziləri əhatə edəcəyini və digər müsəlman ölkələrində də bu cür xoşagəlməz hadisələrin yaşana biləcəyi ehtimalını artırır. Təcrübə müasir dövrdə bu cür problemləri yalnız zor və silah gücü ilə tam həll etməyin mümkün olmadığını göstərir. Belə olduğu halda vəziyyətdən çıxış yolu tapmaq və gənclərimizi zərərli təsirlərdən qorumaq üçün biz nə etməliyik?

Heç şübhəsiz ki, dünyada, xüsusilə də müsəlman ölkələrində cərəyan edən hadisələr bölgəyə təsirsiz ötüşmür. Son günlər baş verənlər həmin hadisələrin Son dövrlər bir sıra müsəlman dövlətlərində radikallıq meyillərinin artması və qarşıdurmaların yaranması bilavasitə bölgədə və dünyada baş verən proseslərlə sıx bağlıdır. Müsəlman ölkələrində cərəyan edən siyasi hadisələr, daxili qarşıdurmalar, sosial problemlərin uzun müddət həll olunmaması və münaqişələrin həllinə ikili standartlarla yanaşma bu meyillərin artmasına münbit şərait yaradır. ölkəmizdə dini duruma ciddi təsir etdiyini, bu proseslərin qarşısını almağa tam hazır olmadığımızı, xarici təsirlərin getdikcə ölkədə daha geniş yayıldığını və daxili təbliğatın xarici təbliğata rəqabətdə uduzduğunu göstərir. Bir sıra hallarda ölkədəki dini duruma xaricdən müdaxilələr edilir, müəyyən yerli və xarici dairələr Azərbaycanda dini durumu gərginləşdirməyə və öz siyasi maraqlarını həyata keçirməyə çalışırlar.

Beləliklə cəmiyyətin dinclik və xoşbəxtliyinə səbəb olan dinin, əhalinin dinclik və etibarını təhdid edəcək şəkildə terrorçu və ekstremist qruplar tərəfindən istismarı dövlət təhlükəsizliyi üçün böyük təhdid yaradır. Məqalədə bu kimi 
halların qarşısının alınması, ekstremizmlə mübarizədə yaranan problemlər, dinlərarası dialoqların vacibliyi əks olunmuşdur.

\section{References}

1. Azerbaycan Respublikasinda dovlet-din munasibetlerini tenzimleyen resmi senedler [Official documents regulating the state and religion relations in Azerbaijan Republic]. Baku, Elm ve Tehsil, 2015.

2. Huseynov Sakit. Azerbaycanda dini tolerantliq medeniyyeti: tarix ve muasirlik [Religion tolerant culture in Azerbaijan: history and modernity]. Baku, Teknur, 2012. $72 \mathrm{p}$.

3. Orucov Hidayet. Azerbaycanda din: en qedim dovrden bu gunedek [Religion in Azerbaijan: from ancient period to nowadays]. Baku, CBS Polygraphic production, 2012. $267 \mathrm{p}$.

4. Kaushanskyi P.L. Religiya i grozyaschaya katastrofa. Problema yedineniya religii pered litsom global'nykh ugroz sovremennosti [Religion and impending catastroph. Problem of religion unity to face of global threats of modernity]. S. Peterburg, 1994, $150 \mathrm{p}$.

5. Tushkova Yu.V. Otlichiya i skhodstva v ponyatiakh "radikalizm" i “ekstrimizm” v zakonodatel'stve i sotsial'no-politicheskikh naukakh Velikobritanii [Differences and similarities in the concepts "radicalism" and "extremism" in legislation and socio-political sciences of Great Britain]. Molodoyi uchenyi Journal [Young Scientist], 2014, no. 5, p. 435. 